\title{
Preliminary Canopy Removal Experiments in Algal Dominated Communities Low on the Shore and in the Shallow Subtidal on the Isle of Man
}

\author{
S. J. Hawkins and E. Harkin \\ Department of Zoology, Manchester University, Manchester M13 9PL, U.K. \\ and \\ Department of Marine Biology, Liverpool University, Port Erin, Isle of Man
}

(Accepted January 22, 1985)

\begin{abstract}
The algal dominated communities immediately above and below the low-water spring level on a moderately exposed Manx shore were investigated by canopy removal experiments. Fucus serratus, Laminaria digitata and $L$. hyperborea were removed. Competition was shown to be important in determining the zonation of $L$. digitata and the distribution along the wave exposure gradient of other species such as Alaria esculenta, Desmarestia aculeata and $D$. viridis, and $L$. saccharina. Many species of algal epiphytes were early colonizers of canopy removal areas suggesting that competition from canopy algae usually restricts them to an epiphytic habit. The results indicate that interactions between macrophytes are much more important than grazing in structuring these communities.
\end{abstract}

\section{Introduction}

The lower-shore and immediate sub-tidal regions of all but the most sheltered N. W. European coasts are usually dominated by canopies of large algae. Fucus serratus, Laminaria digitata, L. hyperborea are particularly abundant usually forming clearly defined zones on stable substrata. However, Himanthalia elongata, Laminaria saccharina, and Alaria esculenta can be locally important depending on shore topography, exposure and season (see Lewis 1964, Kain 1979 , for reviews).

In this study, competition between canopy species and the influence of the canopy on the rest of the community have been investigated by experimental canopy removal. Previous investigations of canopy interactions have tended to be either sub-tidal only (eg. Whittick 1969, Dayton 1975 a, Kain 1975, Norton et al. 1977, Harkin 1981 a, Kastendiek 1982), or wholly inter-tidal studies (eg. Dayton 1971, 1975 b, Sousa 1979, Keser and Larson 1984). In contrast, we have investigated using comparable methods, the very similar macrophyte-dominated communities found immediately above and below the low-water spring level. Canopies have been experimentally removed in the Fucus serratus, Laminaria digitata and L. hyperborea zones on the same Manx shore. Algae are named in accordance with the most recent U. K. check list (Parke and Dixon 1976) and animal nomenclature follows the Marine Fauna of the Isle of Man (Bruce et al. 1963). Encrusting calcareous algae, commonly referred to as "lithothamnia", are collectively termed "encrusting corallines".

\section{Methods}

All work was done on the gently sloping limestone ledges at Kallow Point, Port St. Mary, Isle of Man (Lat. $54^{\circ}, 4^{\prime} \mathrm{N}$, Long. $4^{\circ}, 46^{\prime} \mathrm{W}$ ). Full descriptions of these shores can be found in Southward (1953) and Bruce et al. (1963). Experiments were set up at two places: on the moderately-exposed south-eastern tip of Kallow Point and a slightly more sheltered location just south of the Albert Pier (moderately sheltered). Table I summarizes starting dates, locations, initial community composition and the methods used in each experiment. 
Table. 1. Details of each experiment and initial community composition of treatment (T) and control (C) areas. Abundance of canopy atgae, understorey algae and sessile animals expressed as \% cover, other animals as numbers in each area. + indicates present in small amounts, - not found at this level on this shore.

\begin{tabular}{lcccc}
\hline Experiment number & 1 & 2 & 3 & 4 \\
\hline Dominant canopy removed & Fucus serratus & Laminaria digitata & Laminaria digitata & Laminaria hyperborea \\
Exposure & Moderately exposed & Moderately sheltered & Moderately exposed & Moderately exposed \\
Date of canopy removal & August 1978 & March 1978 & October 1978 & April 1979 \\
Area cleared & $2 \mathrm{~m} \times 2 \mathrm{~m}$ plus buffer & $2 \mathrm{~m} \times 2 \mathrm{~m}$ plus buffer & $2 \mathrm{~m} \times 2 \mathrm{~m}$ plus buffer & $2 \mathrm{~m} \times 2 \mathrm{~m}$ plus buffer \\
Height/depth & $0.8 \mathrm{~m}$ above MLWS & MLWS & $0.3 \mathrm{~m}$ below MLWS & $0.8 \mathrm{~m}$ below MLWS \\
Removal frequency & Once & Once & Repeated & Once
\end{tabular}

\section{INITIAL SPECIES COMPOSITION}

\section{CANOPY ALGAE}

Fucus serratus

Himanthalia elongata

Laminaria digitata

Laminaria saccharina

Alaria esculenta

Laminaria hyperborea

$F$ serratus sporelings

Himanthalia buttons

Laminaria sporelings
$\mathrm{T}$

C

$\begin{array}{rr}>95 & >95 \\ 0 & 0 \\ - & - \\ - & - \\ - & - \\ - & - \\ 5 & + \\ + & + \\ 0 & 0\end{array}$

$T$

+
0
$>95$
0
0
-
+
+
+

$\mathrm{C}$

0
0
$>95$
0
0
-
0
+
+

$\mathrm{T}$
C
$\mathrm{T}$

C

\section{UNDERSTOREY ALGAE}

Total Understorey Algae

Corallina officinalis

Cladophora spp.

Palmaria palmata

Gigartina stellata

Chondrus crispus

Lomentaria articulata

Membranoptera alata

Phycodrys rubens

Cryptopleura ramosa

Griffithsia flosculosa

Ptilota plumosa

Halurus equisetifolius

Ceramium rubrum

"Encrusting Corallines"

$\begin{array}{rr}30 & 25 \\ 15 & 10 \\ 10 & 1 \\ 5 & \\ + & \\ + & \\ + & \\ + & \\ - & \\ - & \\ - & \\ - & \\ - & \\ 0 & \\ 60 & \end{array}$

15

10

2

0

0

0

0

0

$-$

$-$

$-$

$-$

0

85

15
10
5
0
0
0
0
0
-
-
-
-
-
0
85

-
0
$>95$
0
0
-
0
+
+

-
0
$>95$
0
0
0
0
+
+

\begin{tabular}{|c|c|}
\hline 6 & 6 \\
\hline 5 & 5 \\
\hline 1 & 1 \\
\hline 0 & 0 \\
\hline 0 & 0 \\
\hline 0 & 0 \\
\hline 0 & 0 \\
\hline 0 & 0 \\
\hline- & - \\
\hline- & - \\
\hline- & - \\
\hline- & - \\
\hline- & - \\
\hline 0 & 0 \\
\hline 95 & 95 \\
\hline
\end{tabular}

$\begin{array}{rr}90 & 90 \\ 80 & 80 \\ 2 & 2 \\ 0 & 0 \\ 0 & 0 \\ 0 & 0 \\ 0 & 0 \\ 0 & 0 \\ + & + \\ + & + \\ + & + \\ + & + \\ + & + \\ + & + \\ + & +\end{array}$

FAUNA

Halichondria panicea Hymeniacidon sanguinea Encrusting bryozoa Patella spp.

5
+
+
3

$\begin{array}{cc}5 & 5 \\ + & 0 \\ + & + \\ 3 & 20\end{array}$

5

10

$\begin{array}{ll}+ & + \\ + & + \\ 0 & 0 \\ 6 & 6\end{array}$

$\begin{array}{cc}+ & + \\ + & + \\ 0 & 0 \\ 0 & 0\end{array}$

An area of canopy was cleared by cutting stipes just above the holdfasts to create each treatment area. An adjacent untouched control was marked-out using dabs of paint, bolts or chiselled holes a short distance away $(1-2 \mathrm{~m})$, care being taken to choose control and treatment areas with initially similar community composition (see Table I). A buffer zone was formed by clearing the canopy for an additional metre around the treatment area in experiments with the large Laminaria plants to avoid edge effects. The canopy was removed once, except in experiment 3 where recolonizing $L$. digitata plants were removed on subsequent visits. Abundance of algae and sessile animals in the whole treatment (except the bufferzone) and control areas was assessed non-destructively by subjective visual estimates aided by contiguous quadrats (inter-tidally, by $0.5 \times 0.5 \mathrm{~m}$ divided into $0.1 \times 0.1 \mathrm{~m}$ sub-quadrats and sub-tidally, by 1.0 
$\times 1.0 \mathrm{~m})$. The accuracy of subjective estimates of this nature has been compared with objective estimates using random-siting dots and they do not differ significantly (Hawkins and Hartnoll 1983a). The eventual differences between the treatments and the controls were much larger than the likely error $( \pm$ $10 \%$ ). The need for non-destructive sampling resulted in some species, which occurred in small amounts, being identified in the field to generic level only.

\section{Results}

Experiment 1. Fucus serratus removal (moderatelyexposed)

Total cover of understorey algae on the control area changed little (Fig. 1). The small winter decrease in canopy in the control is the normal seasonal pattern for this species (Knight and Parke 1950, Hawkins and Hartnoll 1983 a).

A

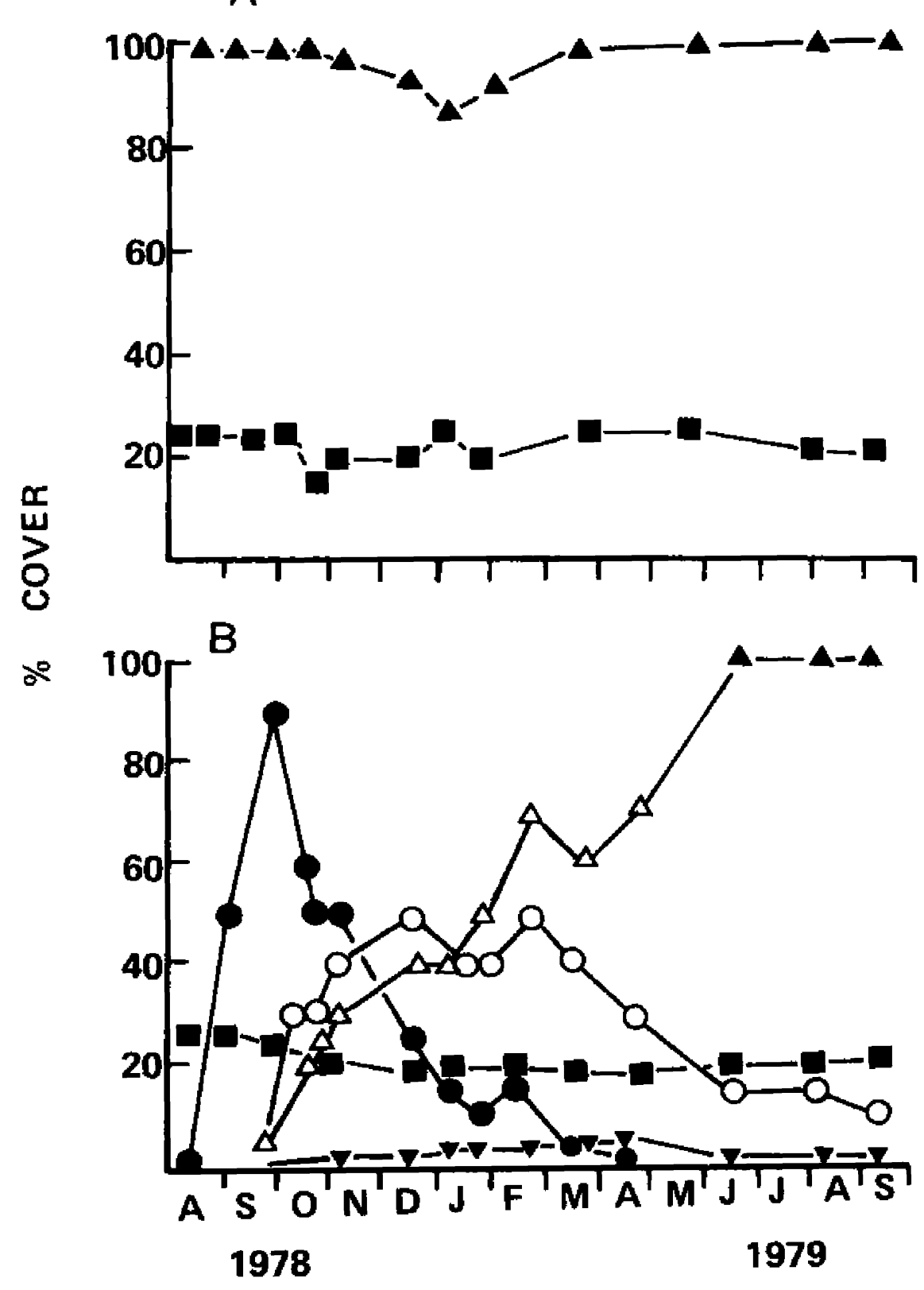

Fig. 1. Fucus serratus removal experiment (1) on a moderately exposed shore. A. Control area: $F$. serratus canopy $(\boldsymbol{\Lambda})$, total permanent understorey algae ( $\boldsymbol{(})$. B. Treatment area: Enteromorpha intestinalis (O), Palmaria palmata $(O), F$. serratus sporelings $(\triangle)$, $F$. serratus canopy $(\boldsymbol{\Delta}), L$. digitata $(\boldsymbol{\nabla})$, total permanent understorey algae (ם).
Upon removal of the canopy, "encrusting corallines", hydroids and bryozoans died within one week. Enteromorpha intestinalis appeared first (Fig. $1 \mathrm{~B})$, rapidly reaching almost total cover. This decreased as Palmaria palmata and Fucus serratus sporelings increased in number and grew to dominate the area. By mid summer 1979 F. serratus had totally recolonized the cleared area. Throughout the experiment, there was very little recruitment of $F u$ cus sporelings under the control canopy, and when present it was associated with winter canopy gaps. Laminaria digitata appeared in the cleared area in November and reached around 5\% cover (20 small plants) by March. The sporelings grew to a considerable size by April $(0.30-0.50 \mathrm{~m})$. Occasional L. digitata sporelings were found among the nearby $F$. serratus canopy, but none over $0.1 \mathrm{~m}$ long. In the spring some of the L. digitata fronds showed bleaching, and the plants were increasingly overgrown and shaded by the growing $F$. serratus sporelings. By the end of the experiment there were only 1 or 2 stunted $L$. digitata plants left. The more permanent understorey algae (Cladophora rupestris and Corallina officinalis) became covered to some extent by Enteromorpha intestinalis, $P$. palmata and $F$. serratus, and decreased in cover but still survived. Enteromorpha grew both on and among the understorey, whereas Palmaria and Fucus shaded the plants by growth from gaps in the understorey turf.

Experiment 2. Laminaria digitata removal (moderately-sheltered)

There was little change in the control area (Fig. 2A) except a slight autumn and winter decrease in canopy cover, presumably due to storm losses. Concurrently a few (not shown on Fig. 2) L. digitata sporelings appeared under the canopy, usually in the obvious gaps. The total "understorey algae" also seemed to increase slightly in the control though this may have been due to the difficulty of making accurate estimates under the dense $L$. digitata canopy.

Upon removal of the canopy considerable changes occurred in the treatment area. The "encrusting corallines" became bleached and colonized by successive algal phases (see Fig. 2C). Brown filamentous algae (mainly Ectocarpus sp.) rapidly formed a complete cover over the surface by the end of April, decreasing as they were replaced by green algae (Ulva lactuca, Enteromorpha spp., Monostroma grevillei, Spongomorpha sp. and a Cladophora sp. [not rupestris]) and a large cover of small unidentifiable laminarian sporelings (see Fig. 2B). Palmaria palmata increased as the green algae declined, reaching a peak in July, subsequently decreasing, as Laminaria spp. increased rapidly in late summer/autumn (Fig. 2B). 
A

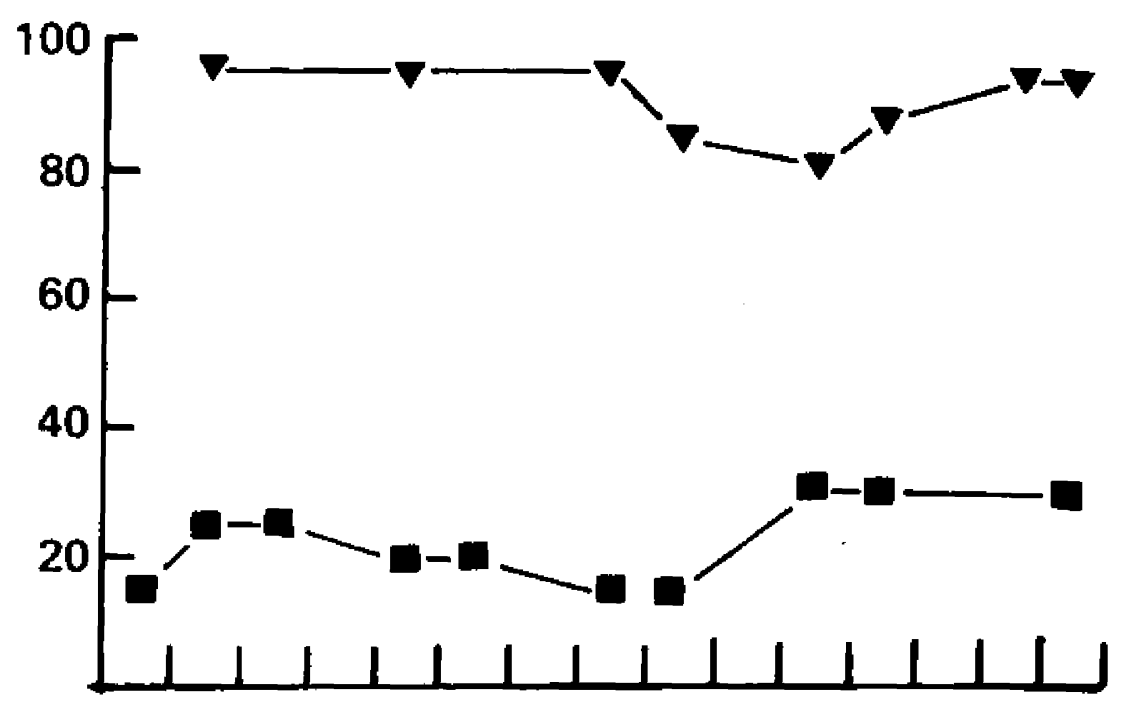

B

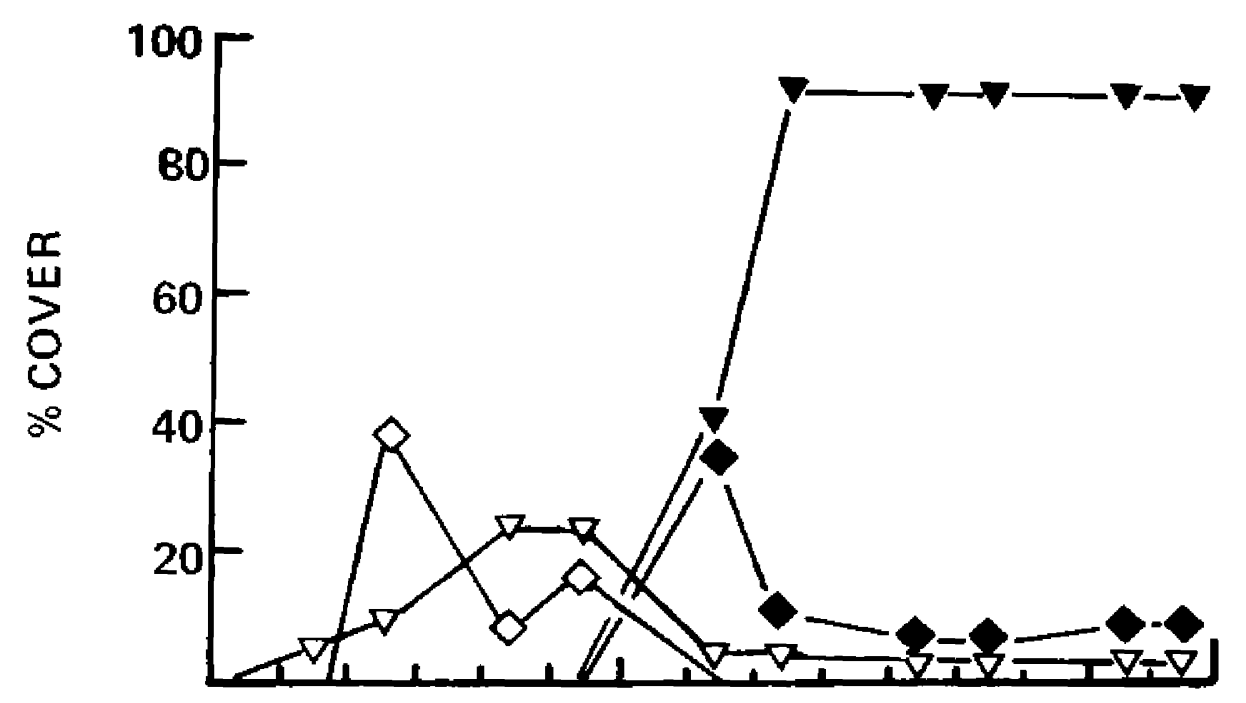

$\mathrm{C}$

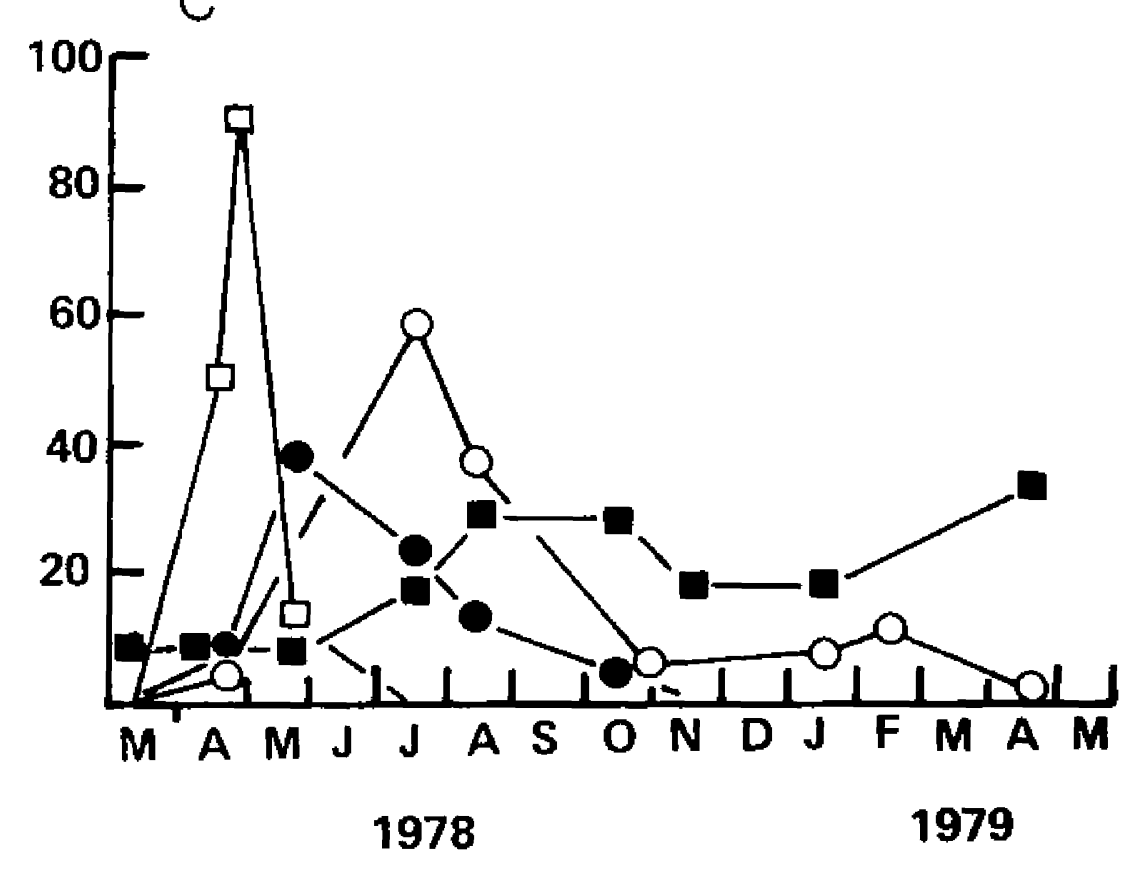

Fig. 2. Laminaria digitata removal experiment (2) on a moderately sheltered shore. A. Control area: $L$. digitata canopy $(\boldsymbol{\nabla})$, total permanent understorey algae ( $\boldsymbol{\square})$. B. Canopy forming species in treatment area: Unidentified laminarian sporelings $(\diamond), L$. saccharina $(\diamond), L$ digitata $(\boldsymbol{\nabla})$, Alaria esculenta $(\nabla)$. C. Substratum covering species in treatment area: Brown filamentous algae $(\square)$. green algae (๑), Palmaria palmata $(\bigcirc)$, total permanent understorey algae $(\mathbf{D})$.

The total "understorey algae" also increased through the addition of species of red algae such as Cystoclonium purpureum and Ceramium ciliatum. The brown filamentous algae and $P$. palmata were common epiphytes on the surrounding $L$. digitata plants and probably were recruited from this source.
Alaria esculenta (see Fig. 2B) appeared soon after removal in the treatment and reached $25 \%$ cover, but was never found in the control or the surrounding intertidal area (50 m, either side). Many of the unknown laminarian sporelings grew rapidly and presumably outcompeted the Alaria, as few plants of the latter remained in October. By the middle of October half of the newly recruited Laminaria plants were $L$. digitata, the others were $L$. saccharina. $L a$ minaria saccharina decreased rapidly in early winter; observations suggested that this was caused by storm loss. Laminaria digitata regained total cover by November 1978, six months after the start of the experiment. Some $F$. serratus plants were present in the removal area from July onwards but never achieved more than $5 \%$ cover and eventually seemed completely overshadowed by $L$. digitata.

The dense growth of algae on the rock surface in the treatment area resulted in the free space surrounding the limpets becoming smaller and smaller and eventually they could not be found despite thorough searching. Thus they were smothered by algae rather than moving away. They only returned in smaller numbers as the Laminaria canopy was restored and the substrate covering algae declined. Patella remained in the control throughout the experiment.

Experiment 3. Laminaria digitata removal (moderately-exposed)

In the control there was no noticeable change in understorey algae (Fig. 3A) and recruitment of $L$. digitata sporelings was low. The canopy decreased to $80 \%$ in the winter in a similar way to the previous experiment.

By January 1979 little change had occurred in the treatment area except that a small amount of a brown filamentous alga (Ectocarpus) plus a few $F$. serratus germlings had appeared (see Fig. 3B). A large number of $L$. digitata sporelings, present at the end of February, were removed. Brown filamentous algae (Ectocarpus sp.) formed a considerable cover by the end of March, reaching a peak in mid April; but decreased subsequently as $P$. palmata, Himanthalia elongata and $A$. esculenta increased in cover. Green algae, including Spongomorpha sp. and $U$. lactuca (briefly) appeared in small amounts. Himanthalia elongata formed an appreciable canopy but was rapidly overtopped by $A$. esculenta and subsequently decreased, as did P. palmata. Alaria esculen$t a$ had formed an almost complete canopy by the end of the experiment. 
A
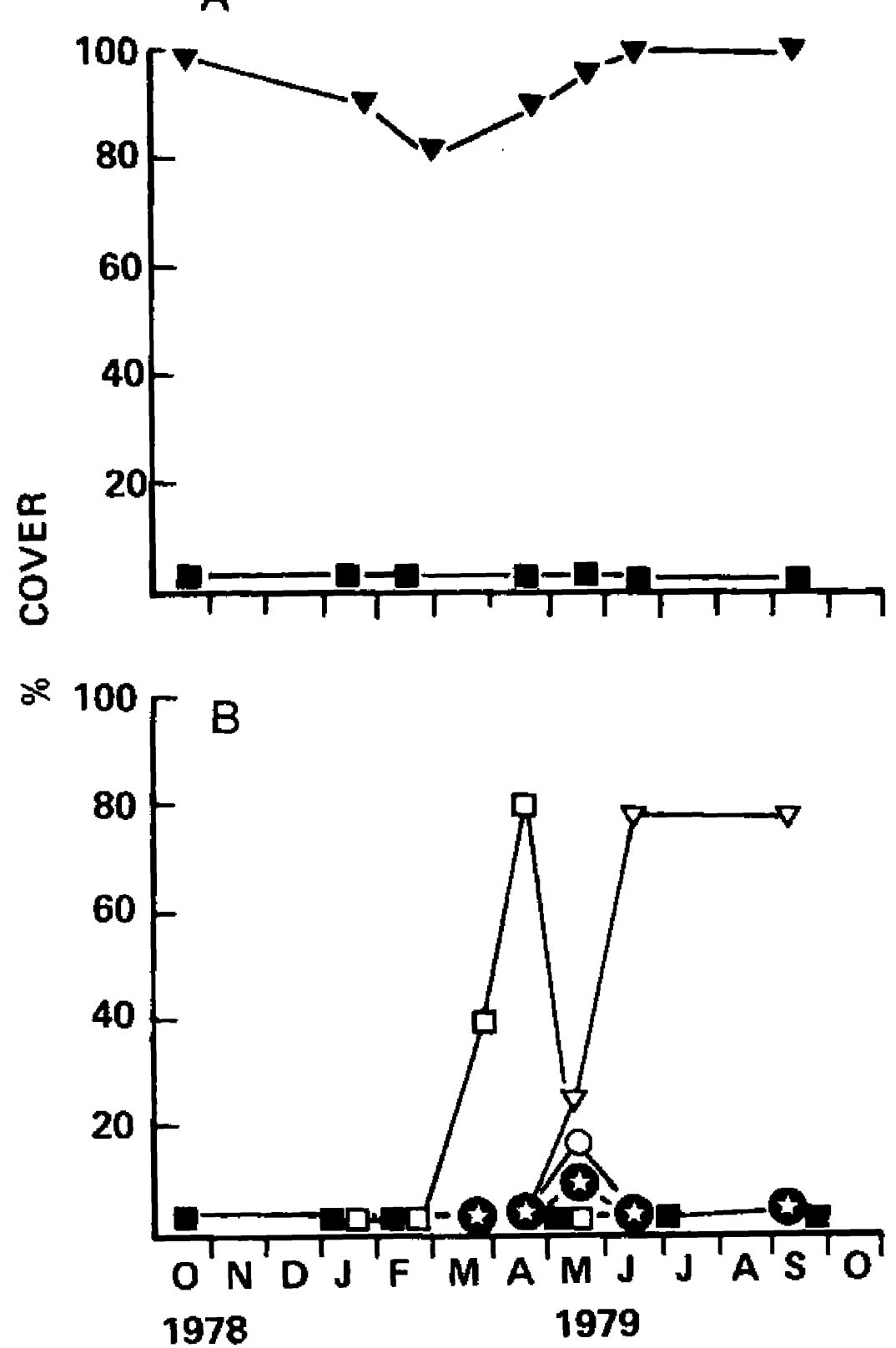

Fig. 3. Laminaria digitata removal experiment (3) on a moderately exposed shore. A. Control area: $L$. digitata canopy $(\boldsymbol{\nabla})$, total permanent understorey algae (D). B. Treatment area: Brown filamentous algae $(\square)$, Alaria esculenta $(\nabla)$, Palmaria palmata $(O)$, Himanthalia elongata $(\boldsymbol{\Theta})$, total permanent understorey algae $(\boldsymbol{\square})$.

Experiment 4. Laminaria hyperborea removal (moderately-exposed)

Little change occurred in the control area throughout the experiment (Fig. 4A).

Palmaria palmata occurred as an epiphyte on the stipe of Laminara hyperborea at this site and within a month of canopy removal, it was abundant on the residual holdfasts in the treatment area. At this stage also, $A$. esculenta was present in the treatment area (Fig. 4B) along with solitary Saccorhiza polyschides, H. elongata and Dilsea carnosa plants. The understorey cover in both treatment and control areas remained as listed in Table $\mathrm{I}$.

By June, the treatment area was dominated by Alaria with some plants over one metre long. A tangled mixture of Desmarestia aculeata and $D$. viridis made up the rest of the canopy cover. The understorey cover in both treatment and control areas remained unchanged and $P$. palmata still dominated the holdfasts in the treatment. Throughout the rest of the

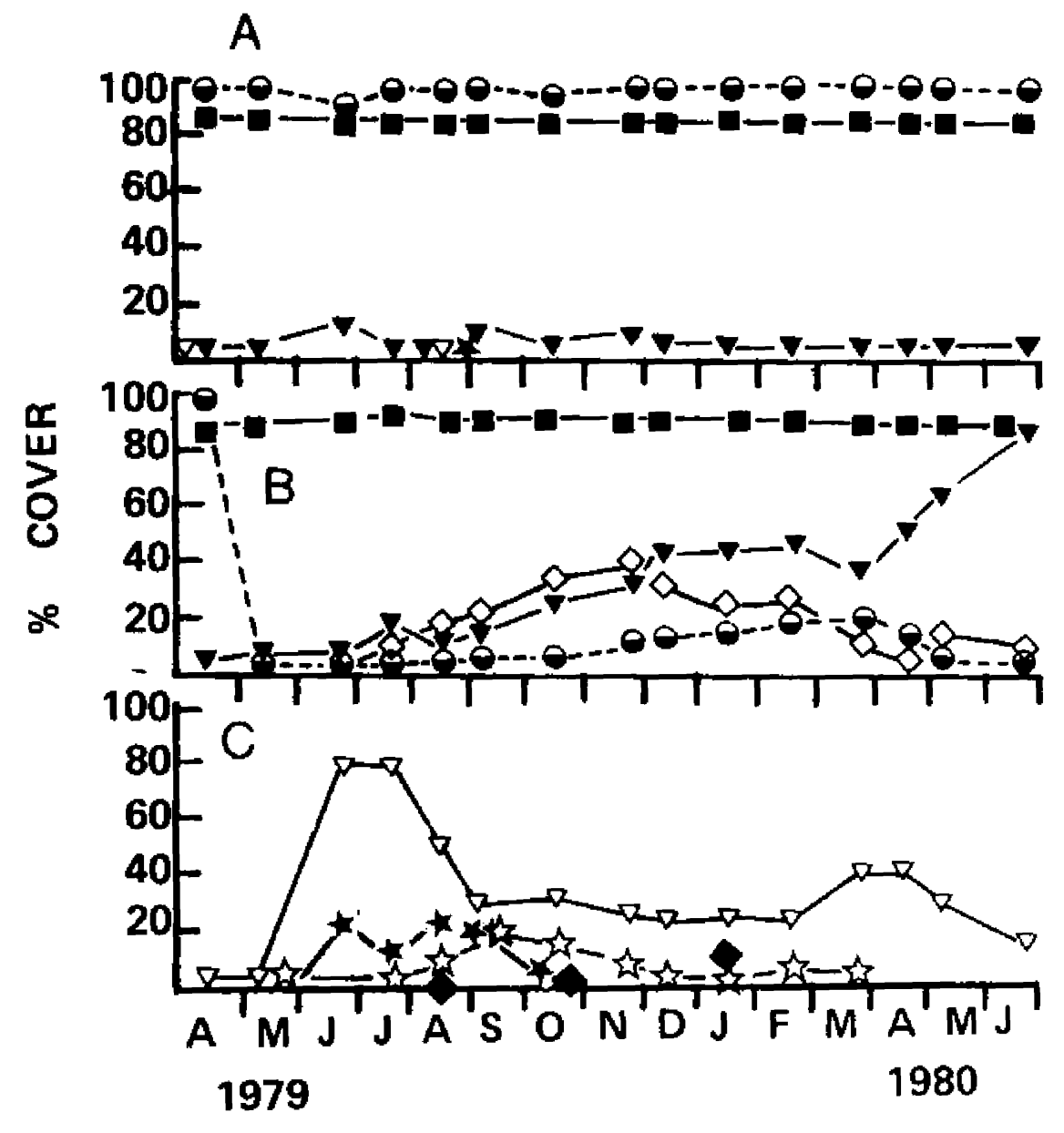

Fig. 4. Laminaria hyperborea removal experiment (4) on a moderately exposed shore. A. Control area: $L$. hyperborea (-- --$), L$. digitata $(\nabla)$, Alaria esculenta $(\nabla)$, Desmarestia spp. ( $\star$ ), total permanent understorey algae (ם). B. Treatment: Laminaria hyperborea $\left(--_{--)}, L\right.$. digitata $(\nabla)$, Laminaria sporelings $(\diamond)$, total permanent understorey algae ( $\mathbf{\square})$. C. Treatment: Alaria esculenta

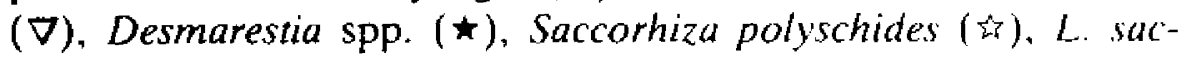
charina (४).

summer and autumn of 1979 , the $A$. esculenta gradually declined in the treatment area so that by September, its cover was almost equal to that of the Desmarestia spp. and Saccorhiza polyschides (Fig. 4C). During this period, unidentifiable Laminaria sporelings and $L$. digitata were also increasing (Fig. 4B). The Laminaria sporelings tended to occur on holdfasts dominated by $P$. palmata which subsequently declined.

During the following winter, the cover of Desmarestia spp. disappeared very quickly in the treatment area probably due to death of the annual $D$. viridis. Saccorhiza polyschides declined more slowly. Density of $A$. esculenta, however, remained stable while $L$. digitata continued to increase together with young Laminaria plants of which just over half were $L$. digitata, the remainder, L. hyperborea. The single Himanthalia specimen still remained along with some scattered individuals of $L$. saccharina.

By the beginning of 1980 , the treatment area had become co-dominated by $A$. esculenta and $L$. digitata in a dense canopy below which the Laminaria sporelings gradually disappeared. In the spring of $1980, A$. esculenta increased again for a short period but declined during the summer as $L$. digitata grew rapidly. 
By June, at the end of the experiment, the treatment area was dominated by a dense canopy of $L$. digitata with stipe lengths of up to $60 \mathrm{~cm}$. Alaria esculenta was still present, as were a small number of $L$. hyperborea. Below this canopy, the cover of Laminaria sporelings was about the same as in the control, but with two thirds $L$. digitata and one third L. hyperborea. In contrast, two thirds of the Laminaria sporelings in the control were L. hyperborea and one third L. digitata.

Throughout the experiment the cover of understorey algae remained the same in both the treatment and the control, consisting of a dense mat of Corallina officinalis over $95 \%$ of the available rock surface.

\section{Discussion}

Competition from Fucus serratus was evidently an important factor affecting the upper limit of Laminaria digitata, though unusually hot weather can also be responsible (Hawkins and Hartnoll 1985). The lower limit of $L$. digitata was shown to be determined by competition from L. hyperborea, confirming the indications shown in Kain's (1975) work. In another experiment (Hawkins 1979) selective removal of $L$. digitata below the $F$. serratus and Himanthalia elongata zones, resulted in both Himanthalia and $F$. serratus establishing themselves in greater quantity lower down the shore. In the sub-tidal, Hruby (1976) attributed control of the lower limit of Iridaea cordata to competitive interactions with more rapidly growing laminarians. These results suggest the balance in competitive ability switches from one species to the next at zonal boundaries low on the shore - in keeping with the hypotheses of Pielou (1974) and Chapman (1973, 1974).

Competition was also shown to be the prime direct cause of distribution patterns of $L$. saccharina, A. esculenta, Sacchoriza polyschides and Desmarestia aculeata and $D$. viridis in the moderately-exposed part of the wave action gradient on the shores studied. $L$. saccharina is a short-lived species often found on stones and boulders on unstable substrata usually in more sheltered conditions (Park 1948, Kain 1979, for review). Alaria is more usually found on exposed shores (Lewis 1964). Removal of the L. digitata canopy induced the unusual occurrence of both growing next to each other in an area where neither previously existed. Thus both species are usually excluded by competition from $L$. digitata from solid rock on shores of moderate exposure. Similarly in the subtidal, $L$. hyperborea out-competes $A$. esculenta, S. polyschides and D. aculeata and $D$. viridis, all of which are usually found on unstable boulder substrates in the sub-tidal, where a canopy of the dominant $L$. $h y$ perborea cannot form. These species recruit primarily from "reservoir" populations in exposed or unstable areas where competitive superiors cannot dominate totally. Reservoirs allow exploitation of transiently available areas of unoccupied space which may arise naturally due to disturbance caused by strong storms. Interestingly, S. polyschides dominates the sub-tidal in areas of Southern Europe such as the Algarve coast of Portugal where L. hyperbo$r e a$ and $L$. digitata do not occur (Hawkins, unpublished observs.). Thus competitive canopy interactions are as important in setting species distributions in low shore and shallow subtidal communites in $\mathrm{N}$. W. Europe as they are on the Pacific coast of America (e.g. Dayton 1975a, Kastendiek 1982).

Many of the initital colonizers of open space in all the experiments were epiphytes on canopy algae in the surrounding area (e.g. Palmaria on F. serratus, $L$. digitata and $L$. hyperborea; Ectocarpus spp. on $L$. digitata; Enteromorpha spp. on $F$. serratus). Thus competition appears to restrict these species to a primarily epiphytic existence. Epiphytes may therefore also constitute a reservoir from which recruitment of ephemeral species can occur to other, often transient, habitats.

More of the rock surface was covered by understorey algae beneath $L$. hyperborea than under $L$. digitata. The changes following canopy removal were also of greater magnitude in the $L$. digitata experiment. Both these observations suggest that the effects of the canopy of the more erect $L$. hyperborea upon the sub-canopy epilithic flora are less than those of $L$. digitata. Although L. hyperborea forms a very effective barrier to light (Kain 1971, 1979), the greater effect of $L$. digitata can be attributed to its more flexible stipe coupled with greater water movement at low water spring level than in the immediate sub-tidal. Together these result in the whole plant sweeping over the rock surface to a much greater extent, having a direct mechanical effect on sporeling or germling settlement. Velimirov and Griffiths (1979) have shown similar sweeping effects with the South African kelp, Laminaria pallida, which although it does not have a flexible stipe, sweeps the surface with its extensive lamina. An unswept zone immediately surrounds the stipe of $L$. pallida allowing settlement of algae - this does not appear to occur with L. digitata.

Patella vulgata were rare in the $F$. serratus and $L$. digitata zone (Table I). Removal of the canopy resulted in the limpets being smothered by a profusion 
of rapidly growing algae, whose growth-rate exceeded the limpets' grazing capability. Thus the limpets' presence is facilitated by the sweeping action of macrophytes, particularly $L$. digitata, which maintains a surface coated with "encrusting corallines" on which they can readily graze small algae and newly settled sporelings (see Branch 1981 and Hawkins and Hartnoll 1983b for reviews of limpet feeding capabilities). Recent work in Australia (Underwood and Jernakoff 1981) and in Britain (Hawkins 1979 and unpublished) has shown that a point exists low on the shore at which the ability of algae to grow rapidly exceeds the ability of the limpet population to graze. Similarly, Ballantine (1961) commented upon the precarious nature of Patella populations under canopies and in clearings among algae low on the shore. In the British Isles, sea urchins (Echinus) are rare in areas like Kallow Point, Port St. Mary, with gently sloping wave-beaten subtidal rock without sheltering crevices (Harkin 1981b). Even where highly abundant, their numbers are reduced in the vicinity of the lowest astronomical tides (L.A.T.) level in exposed areas (Jones and Kain 1967). Chapman (1981) made similar observations in Canada. Thus it would seem that in the macrophyte dominated region which spans the boundary between the intertidal and subtidal on N. W. European shores, canopy effects are the dominant biological factors structuring the community. Grazing by limpets is important in the mid intertidal of these shores (Hawkins and Hartnoll 1983b for review) and depending on topography grazing by sea urchins becomes increasingly important at greater depths in the subtidal (Jones and Kain 1967, Kain 1979 for review).

\section{Acknowledgements}

This work was funded by an N. E. R. C. research studentship to S. J. H. and a Northern Ireland Education Authority post-graduate award to E.H.

Professor Naylor kindly provided research facilities at Port Erin. We would both like to thank Drs. R. G. Hartnoll, J. M. Jones and G. Russell for guidance throughout the study.

\section{References}

Ballantine, W. J. 1961. The population dynamics of Patella vulgata and other limpets. Ph. D. thesis, Queen Mary's College University of London. $236 \mathrm{pp}$.

Bruce, J. R., J. S. Colman and N. S. Jones. 1963. Marine Fauna of the Isle of Man. L.M.B.C. Mem. typ. Br. Mar. Pl. Anim. 36: Liverpool University Press. 307 pp.

Chapman, A. R. O. 1973. A critique of prevailing attitudes towards the control of seaweed zonation on the seashore. Bot. Mar. 16: 80-82.

Chapman, A. R. O. 1974. The ecology of macroscopic marine algae. Ann. Rev. Ecol. Syst. 5: 65-80.

Chapman, A. R. O. 1981. Stability of sea urchin dominated barren grounds following destructive grazing of kelp in St. Margaret's Bay, Eastern Canada. Mar. Biol. 62: 307-311.

Dayton, P. K. 1971. Competition, disturbance and community organisation: the provision and subsequent utilization of space in a rocky intertidal community. Ecol. Monogr. 41: 351-389.

Dayton, P. K. 1975 a. Experimental studies of algal canopy interactions in a sea otter dominated kelp community at Amchitka Island, Alaska. Fish. Bull. 73: 230-237.

Dayton, P. K. 1975 b. Experimental evaluation of ecological dominance in a rocky intertidal algal community. Ecol. Monogr. 45: $137-159$.

Harkin, E. 1981 a. Fluctuations in epiphyte biomass following $L a-$ minaria hyperborea removal. Proc. Int. Seaweed Symp. 10: 303-308.

Harkin, E. 1981 b. Field studies on seasonality and canopy effects in Laminaria hyperborea communities. Ph. D. thesis, University of Liverpool. 97 pp.

Hawkins, S. J. 1979. Field studies on Manx shore communities. $\mathrm{Ph}$. D. thesis, University of Liverpool. $238 \mathrm{pp}$.
Hawkins, S. J. and R. G. Hartnoll 1983 a. Changes in a rocky shore community: an evaluation of monitoring. J. Mar. Env. Res. 9: $131-181$.

Hawkins, S. J. and R. G. Hartnoll. 1983 b. Grazing of intertidal algae by marine invertebrates. Oceanogr. Mar. Biol. Ann. Rev. 21: 195-282.

Hawkins, S. J. and R. G. Hartnoll. 1985. Factors controlling the upper limits of intertidal canopy algae. Mar. Ecol. Prog. Ser. 20: $265-271$.

Hruby, T. 1976. Observations of algal zonation resulting from competition. Estuar. Cstl. Mar. Sci. 4: 231-233.

Jones, N. S. and J. M. Kain. 1967. Subtidal algal colonization following the removal of Echinus. Helgoländer wiss. Meeresunters. 1: $460-466$.

Kain, J. M. 1971. Synopsis of biological data on Laminaria hyperborea. FAO Fish. Synops. 87: 74 pp.

Kain, J. M. 1975. Algal recolonization of some cleared subtidal areas. J. Ecol. 63: 739-765.

Kain, J. M. 1979. A view of the genus Laminaria. Oceanogr. Mar Biol. Ann. Rev. 17: 101-163.

Kastendiek, J. 1982. Competitor-mediated co-existance: interactions among three species of benthic macro-algae. $J$. Exp Mar- Biol. Ecol. 62: 201-211.

Keser, M. and B. R. Larson. 1984. Colonization and growth dynamics of three species of Fucus. Mar. Ecol. Prog. Series 15: $125-134$.

Knight, M. and M. W. Parke. 1950. A biological study of Fucus vesiculosus L. and Fucus serratus L. J. Mar. Biol, Ass. U. K. 29: $439-514$.

Lewis, J. R. 1964. The Ecology of Rocky Shores. English Universities Press Ltd., London. 323 pp. 
Norton, T. A., K. Hiscock and J. A. Kitching. 1977. The ecology of Lough Ine XX. The Laminaria forest at Carrigathorna. J. Ecol. 65: 919-941.

Parke, M. 1948. Studies on British Laminariaceae. I. Growth in Laminaria saccharina (L.) Lamour. J. Mar. Biol. Ass. U.K. 27: $651-709$.

Parke. M. and P. S. Dixon. 1976. Checklist of British marine algae - third revision. J. Mar. Biol. Ass. U. K. 56: 527-594.

Pielou. E. C. 1974. Competition on an environmental gradient. In: (P. van den Driessche, ed.) Proc. Conf. Math. Probl. Biol. Springer-Verlag, Berlin. 184-204 pp.

Sousa, W. P. 1979. Experimental investigations of disturbance and ecological succession in a rocky intertidal algal community. Ecol. Monogr. 49: 227-254.
Southward, A. J. 1953. The ecology of some rocky shores in the south of the Isle of Man. Proc. Trans. Liverpool Biol. Soc. 59: $1-50$.

Underwood, A. J. and P. Jernakoff. 1981. Effects of interactions between algae and grazing gastropods on the structure of a low-shore intertidal agal community. Oecologia (Berl.) 48: $221-233$.

Velimirov, B. and C. L. Griffiths. 1979. Wave-induced kelp movement and its importance for community structure. Bot. Mar. 22: 169-172.

Whittick, A. 1969. The kelp forest ecosystem at Petticol Wick Bay, lat. $55^{\circ} 55^{\prime} \mathrm{N}$, long. $2^{\circ} 09^{\prime} \mathrm{W}$ : an ecological study. MSc. thesis, Durham University. 139 pp. 